\title{
Transcript-Specific Loss-of-Function Variants in VPS16 Are Enriched in Patients With Dystonia
}

\author{
Joohyun Park, MD, Annemarie Reilaender, MD, Jan N. Petry-Schmelzer, MD, Petra Stöbe, PhD, \\ Isabell Cordts, MD, Florian Harmuth, MS, Maren Rautenberg, PhD, Sarah E. Woerz, MD, \\ German Demidov, PhD, Marc Sturm, PhD, Stephan Ossowski, PhD, Eva M.C. Schwaibold, MD, \\ Gilbert Wunderlich, MD, Sebastian Paus, MD, Carsten Saft, MD, and Tobias B. Haack, MD
}

Neurol Genet 2022;8:e644. doi:10.1212/NXG.0000000000000644

\section{Abstract}

\section{Background and Objectives}

Our objective was to improve rare variant interpretation using statistical measures as well as publicly accessible annotation of expression levels and tissue specificity of different splice isoforms. We describe rare VPS16 variants observed in patients with dystonia and patients without dystonia, elaborate on our interpretation of VPS16 variants affecting different transcripts, and provide detailed clinical description of the movement disorder caused by VPS16 variants.

\section{Methods}

In-house exome and genome data sets $(n=11,539)$ were screened for rare heterozygous missense and putative loss-of-function ( $\mathrm{pLoF}$ ) variants in VPS16. Using pext (proportion expressed across transcripts) values from the Genome Aggregation Database (gnomAD), we differentiated variants affecting weakly and highly expressed exons/transcripts and applied statistical measures to systematically identify disease-associated genetic variation among patients with dystonia $(\mathrm{n}=280)$.

\section{Results}

Six different heterozygous pLoFs in VPS16 transcripts were identified in 13 individuals. Three of these pLoFs occurred in 9 individuals with different phenotypes, and $3 \mathrm{pLoFs}$ were identified in 4 unrelated individuals with early-onset dystonia. Although $\mathrm{pLoFs}$ were enriched in the dystonia cohort $\left(\mathrm{n}=280 ; p=2.04 \times 10^{-4} ; 4 / 280\right.$ cases vs 9/11,259 controls; Fisher exact test), it was not exome-wide significant. According to the pext values in gnomAD, all 3 pLoFs observed in the patients with dystonia were located in the highly expressed canonical transcript ENST00000380445.3, whereas 2 of 3 pLoFs detected in 8 individuals without dystonia were located in the first exon of the noncanonical transcript ENST00000380443.3 that is weakly expressed across all tissues. Taking these biological implications into account, $\mathrm{pLoFs}$ involving the canonical transcript were exome-wide significantly enriched in patients with dystonia $(p=$ $1.67 \times 10^{-6} ; 4 / 280$ cases vs $1 / 11,259$ controls; Fisher exact test). All VPS16 patients showed mild progressive dystonia with writer's cramp as the presenting symptom between age 7 and 34 years (mean 20 years) that often progressed to generalized dystonia and was even accompanied by hyperkinetic movements and myoclonus in 1 patient.

\author{
Correspondence \\ Dr. Park \\ joohyun.park@ \\ med.uni-tuebingen.de
}

MORE ONLINE

Videos 


\section{Glossary}

BFMDRS = Burke-Fahn-Marsden Dystonia Rating Scale; CCDS = Consensus Coding Sequence; CCSP = Cologne Clinician Scientist Program; CNV = copy number variation; CORVET = class C core vacuole/endosome tethering; DFG = Deutsche Forschungsgemeinschaft; ECD = ethyl cysteinate dimer; EDTA = ethylenediaminetetraacetic acid; gnomAD = Genome Aggregation Database; HOPS = homotypic fusion and vacuole protein sorting; MAF = minor allele frequency; PANDA = Parkinson neuropsychometric dementia assessment; $\mathbf{p L O F}=$ putative loss of function; SPECT = single-photon emission CT; TWSTRS $=$ Toronto Western Spasmodic Torticollis Rating Scale.

\section{Discussion}

Our data provide strong evidence for VPS16 pLoFs to be implicated in dystonia and knowledge on exon resolution expression levels as well as statistical measures proved to be useful for variant interpretation.

Dystonia is a movement disorder characterized by involuntary muscle contractions often leading to sustained abnormal postures and repetitive movements that can affect 1 or multiple different body regions. ${ }^{1}$ The dystonic syndromes can be classified based on the clinical presentation, age at onset, and etiology. ${ }^{1}$ To date, more than 250 genes have been associated with dystonia. However, approximately $80 \%$ of patients with suspected genetically based dystonia remain without a firm diagnosis after exome or genome sequencing. ${ }^{2,3}$ Among many reasons, an explanation is that routine diagnostic prioritization strategies of clinically relevant DNA variants are mostly individual based and not designed to systematically identify disease-associated genetic variation using statistical measures such as exome-wide significance. In addition, information on the functional relevance of alternatively spliced mRNAs, which may lead to tissue-specific exon expression patterns and protein function, is scarcely integrated in phenotype-driven clinical variant interpretation algorithms. ${ }^{4,5}$ Current interpretation of rare genomic variants is a challenging and time-consuming process relying on existing clinical and experimental data as well as statistical parameters and allele frequencies derived from control databases. To establish the pathogenicity of rare variants of unknown clinical significance, they need to be identified in similarly affected patients, and/or supportive functional or segregation studies are required. In disease genes for which haploinsufficiency is an established pathomechanism, putative loss-of-function variants (pLoFs) are generally considered as pathogenic or likely pathogenic. ${ }^{6}$ As different isoforms exist for most transcription units, publicly accessible annotation of expression levels and tissue specificity of different splice isoforms advance as a key resource to improve the power of a rare variant association study and distinguish functionally relevant changes from apparently benign sequence variation. ${ }^{4}$

VPS16 encodes vacuolar protein sorting-associated protein 16, which is a key component of the 2 tethering protein complexes, CORVET (class $\mathrm{C}$ core vacuole/endosome tethering) and HOPS (homotypic fusion and vacuole protein sorting). ${ }^{7}$ The CORVET complex comprises 6 subunits (VPS3, VPS8, VPS11, VPS16, VPS18, and VPS33A) and regulates early endosome fusion and endosomal maturation. ${ }^{8,9}$ The HOPS complex also consists of 6 subunits (VPS11, VPS16, VPS18, VPS39, VPS41, and VPS33A) and plays an essential role in facilitating the fusion of lysosomes with late endosomes and autophagosomes. ${ }^{10}$ One homozygous missense variant in VPS16 has been associated with adolescent-onset primary dystonia in a consanguineous family. ${ }^{11}$ Recently, loss-of-function variants in VPS16 have been described to cause autosomal dominant early-onset dystonia. ${ }^{12,13}$ Other subunits of the CORVET and HOPS complexes have been related to different recessive neurodegenerative disorders with defective endosomal maturation and/or lysosomal dysfunctions. Biallelic variants in VPS11, VPS33A, and VPS41 have been associated with hypomyelinating leukodystrophy type 12, mucopolysaccharidosis-plus syndrome, and early-onset dystonia with ataxia, respectively. ${ }^{8,912,14,15}$ Here, we provide data on rare VPS16 variants observed in patients with dystonia and patients without dystonia and elaborate on our interpretation of VPS16 pLoFs affecting different transcripts. In addition, we describe detailed disease course of the 4 identified patients with dystonia and compared their clinical presentations with previously published cases.

\section{Methods}

\section{Genetic Investigation}

Exome and genome sequencing were performed at the Institute of Medical Genetics and Applied Genomics Tübingen (Tübingen, Germany) as previously described. ${ }^{16}$ In brief, genomic DNA was extracted from EDTA blood samples. For exome sequencing, an Agilent SureSelect XT library preparation kit in combination with the Human All Exon V7 Enrichment target region (Agilent Technologies, Santa Clara, CA) was used to analyze $>99 \%$ of the coding regions. For genome sequencing, a TruSeq DNA PCR-Free k5it (Illumina, San Diego, CA) was used. Subsequently, prepared libraries were sequenced as paired-end reads $(2 \times 125,2 \times 100$ [exome] or $2 \times 150$ [genome] base pairs) on a HiSeq 2500 or NovaSeq 6000 system (Illumina, San Diego, CA). Generated sequences were analyzed using the megSAP pipeline (github. com/imgag/megSAP) with GRCh37 as the reference genome. We searched for rare variants with a minor allele frequency $(\mathrm{MAF})<0.1 \%$, and variants were prioritized 
A. Identified variants in VPS16

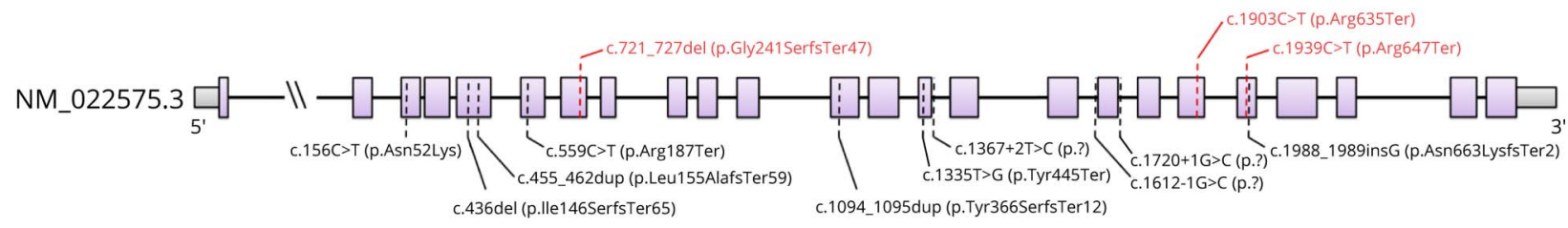

B. Transcripts of VPS16

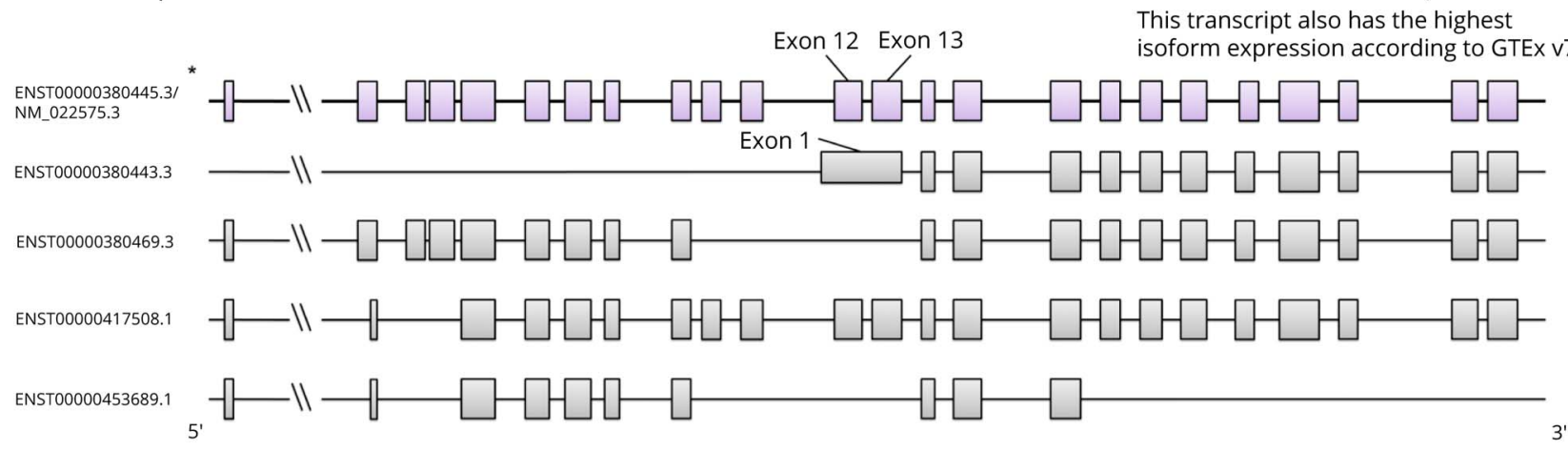

C. Approximate visualization of mean pext

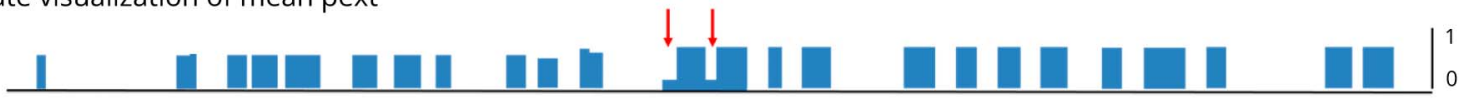

(A) Graphical illustration of VPS16 demonstrates the positions of the identified variants (red lines) and previously published variants in VPS16 (black lines). (B) Different transcripts of VPS16. The Ensembl canonical transcript is marked with an asterisk. (C) Approximate visualization of mean pext (proportion expressed across transcripts) value of VPS16 using GTEx $7^{22}$ transcriptomic sequencing data sets incorporated in gnomAD browser v2.1.1 illustrates normalized value of exon expression levels of all transcripts across all tissues. ${ }^{4}$ All exons of the canonical transcript ENST00000380445.3 show similar expression values, whereas the exon 1 of transcript ENST00000380443.3 shows a notably weaker expression. This exon partly overlaps with the exons 12 and 13 of the canonical transcript. Eight pLoFs were identified in the control group in this exon region that did not overlap with the exons 12 and 13 of the canonical transcript (red arrows).

according to the patient's phenotype using an in-house standard operating procedure. An in-house developed $\mathrm{CNV}$ calling tool was used for copy number variation (CNV) detection.

In-house exome and genome data sets $(n=11,539)$ were screened for rare heterozygous VPS16 variants with an MAF $<0.1 \%$ in gnomAD browser (v2.1.1, Genome Aggregation Database, gnomad.broadinstitute.org) and $<5$ annotations in the inhouse database to exclude pipeline-specific artifacts, followed by manual curation of pLofs and missense variants affecting the Ensembl canonical transcript ENST00000380445.3 (NM 022575.3). For the case-control gene burden analysis, we compared the variant burden of pLoFs as well as rare missense variants in a dystonia cohort of 280 patients with 11,259 individuals without dystonia (i.e., healthy controls and patients with unrelated conditions). pLoFs were annotated as start-lost, stopgain, frameshift, and canonical splice site alterations located \pm 2 nucleotides of the exon-intron boundary. Statistical analysis was performed using R Statistical Software (version 4.0.3, r-project. org/). Statistical differences were evaluated using the 1-sided Fisher exact test and a $p$ value of $<2.5 \times 10^{-6}$ to determine the exome-wide significance corrected for approximately 20,000 Consensus Coding Sequence (CCDS) genes.

\section{Clinical Investigations}

Patients harboring VPS16 variants were examined by different neurologists in Germany, and EDTA blood samples were submitted to the genetic center at the University of Tübingen for diagnostic exome or genome sequencing. Secondary dystonia was excluded in all VPS16 patients before genetic testing. Clinical data were provided after obtaining the genetic outcome.

\section{Standard Protocol Approvals, Registrations, and Patient Consents}

Written informed consent for publication of genetic data, clinical outcome, and video recordings was obtained from all VPS16 patients with dystonia.

\section{Data Availability}

All available clinical data are given within this article. All variants have been deposited into ClinVar (ncbi.nlm.nih.gov/clinvar/) under Institute of Medical Genetics and Applied Genomics, University of Tübingen. 
Table 1 Gene Variant Position, Population Frequency, and In Silico Predictions of VPS16 Variants Identified in Patients With Dystonia

\begin{tabular}{|c|c|c|c|c|c|c|c|}
\hline Patients & $\begin{array}{l}\text { Genomic position } \\
\text { (GRCh37) }\end{array}$ & cDNA position & Protein change & $\begin{array}{l}\text { Allele Count in } \\
\text { gnomAD v.2.1.1 (non- } \\
\text { neuro) }\end{array}$ & CADD & $\begin{array}{l}\text { SIFT/ } \\
\text { PolyPhen }\end{array}$ & REVEL \\
\hline Patient 1 & $\begin{array}{l}\text { chr20:2841703-2841709 } \\
\text { ACAGGCT >- }\end{array}$ & c.721_727del & p.(Gly241SerfsTer47) & NP & NA & NA & NA \\
\hline $\begin{array}{l}\text { Patients } 2 \\
\text { and } 3\end{array}$ & $\begin{array}{l}\text { chr20:2845277- } \\
2845277 \text { C }>\text { T }\end{array}$ & c. $1903 C>T$ & p.(Arg635Ter) & 1 & 37.00 & NA & NA \\
\hline Patient 4 & $\begin{array}{l}\text { chr20:2845636- } \\
2845636 C>T\end{array}$ & c. $1939 \mathrm{C}>\mathrm{T}$ & p.(Arg647Ter) & 1 & 41.00 & NA & NA \\
\hline
\end{tabular}

Abbreviations: $\mathrm{AF}=$ allele frequency; $\mathrm{NA}=$ not applicable; $\mathrm{NP}=$ not present.

\section{Results}

\section{Genetic Testing}

A total of 13 pLoFs carriers were detected in our exome and genome data sets $(\mathrm{n}=11,539)$, whereas only 5 of them had pLoFs affecting the coding sequence of the Ensembl canonical transcript ENST00000380445.3 (NM_022575.3). All others had pLoFs located within the first exon of the Ensembl transcript ENST00000380443.3, which did not overlap with the exons 12 and 13 of the canonical transcript (Figure 1A, 1B).

One heterozygous $\mathrm{pLoF}$ was found in the group with individuals without dystonia $(n=11,259)$, and 3 different heterozygous $\mathrm{pLoFs}$ were identified in 4 unrelated individuals in the dystonia cohort ( $\mathrm{n}$ = 280). Copy number variations encompassing VPS16 were not observed in our in-house database. Patient 1 carries a frameshift variant, c.721_727del (p.Gly241SerfsTer47), patients 2 and 3 a stop-gain variant, c.1903C $>\mathrm{T}$ (p.Arg635Ter), and patient 4 a different stop-gain variant, c.1939C $>\mathrm{T}$ (p.Arg647Ter) (Table 1, Figure 1A). The latter 2 stop-gain variants are each listed once in gnom $\mathrm{AD}$ (non-neuro cohort, gnomAD v2.1.1) in a heterozygous state. All other dystonia genes were tested negative in the 4 patients via diagnostic exome sequencing including SGCE. Family members were not available for segregation analyses.

The enrichment of pLoFs affecting the canonical transcript ENST00000380445.3 was exome-wide significant in patients with dystonia ( $p=1.67 \times 10^{-6} ; 4 / 280$ cases vs $1 / 11,259$ controls; Fisher exact test). In gnomAD version 2.1.1 (non-neuro cohort) containing 114,704 samples, there were 50 heterozygous pLoFs influencing the ENST00000380445.3 transcript $(p=9.89$ $\times 10^{-6} ; 4 / 280$ cases vs $50 / 114,704$ controls, Table 2$)$. Eleven missense variants (ENST00000380445.3/NM_022575.3) were identified in the dystonia cohort, 285 in the nondystonia group, and a total of 8,228 in gnomAD browser. Missense variants in VPS16 were not significantly enriched in the dystonia group $(p=$ 0.17 ; $11 / 280$ cases vs $285 / 11,259$ controls, Table 2 ).

\section{Clinical Phenotypes}

\section{Patient 1 [c.721_727del (p.Gly241SerfsTer47)]}

This 64-year-old woman of Italian origin reported that tremorlike symptoms and abnormal dystonic posture of both hands started at age 26 years. She was diagnosed with writer's cramp and focal hand dystonia. Her previous medical history was unremarkable. She had normal psychomotor development and did not have any complicated hospitalizations. At age 63 years, neurologic examination revealed jerky, irregular, and hyperkinetic movements of the upper extremities reported as mild progressive myoclonus with head tremor (yes-yes), torticollis to the right, and hand dystonia. There were mild signs of resting and postural tremor that was often overshadowed by the hyperkinetic movements (Video 1). These movements were in part compensatory, but also involuntarily compatible with myoclonic jerks. However, no EMG has been conducted to further investigate the myoclonus. Her gait was rather normal with a slight internal rotation of the right foot and reduced arm swing. Blood and CSF laboratory testing including copper metabolism showed no signs of secondary dystonia. MRI of the brain, dopamine transporter scan, and multiple EEG recordings were normal. Pharmacotherapy including tetrabenazine, tiapride, levodopa, baclofen, olanzapine, primidone, and topiramate was ineffective. Only botulinum toxin was effective for treatment of torticollis. Alcohol consumption did not alleviate the myoclonus or tremor. Thiamine and cannabidiol also had no effects. Current treatment with gabapentin has mildly improved her symptoms. She was born to nonconsanguineous Italian parents, who both deceased after age 75 years without showing any neurologic deficits. This patient has 6 siblings, and 2 of her deceased brothers apparently showed similar clinical signs. Her children and grand children are healthy.

\section{Patient 2 [c.1903C >T (p.Arg635Ter)]}

In patient 2, a 65-year-old German woman, disease onset was at age 14 years with dystonia of the left foot. It progressed slowly over the years, expanding to the neck (cervical dystonia), the right hand, the left hand, speech (slight laryngeal dystonia), and, finally, the trunk. Presumably, disease progress stabilized at age 25 years. When examined at age 65 years, the most prominent symptom of generalized dystonia was cervical posturing with slight head tremor. Second, dystonic posturing of the left foot was bothersome and painful, intensified by walking. There was dystonic posturing and tremor of the right hand triggered by movements such as writing, accompanied by some myoclonic jerks. Dystonia of the trunk, left hand, and speech was minor (Video 2). Family 


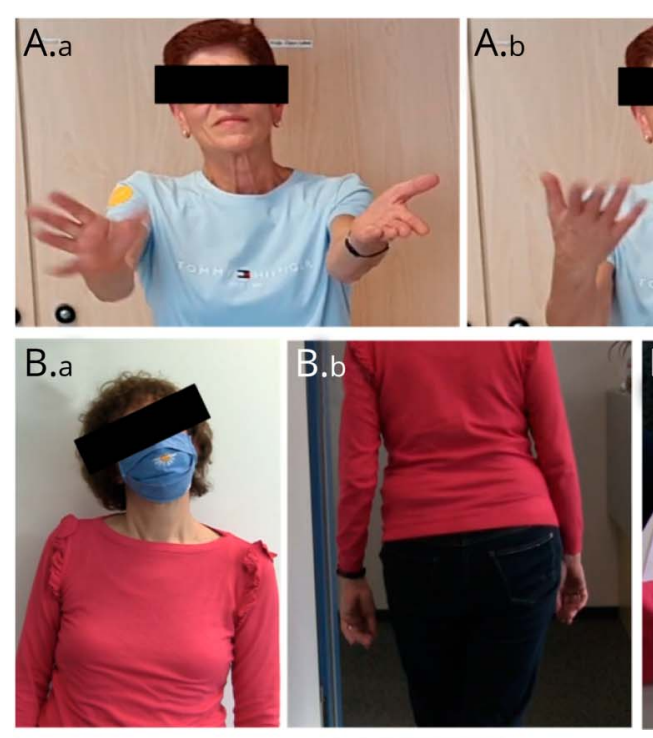

C.a

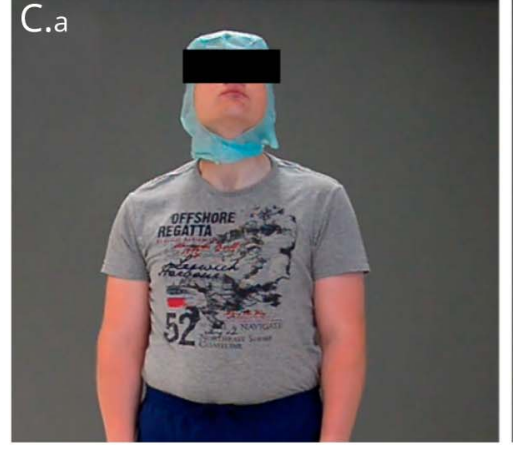

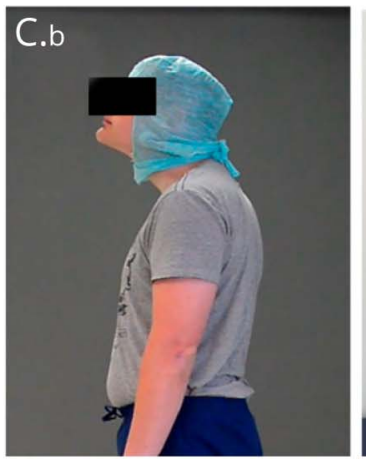

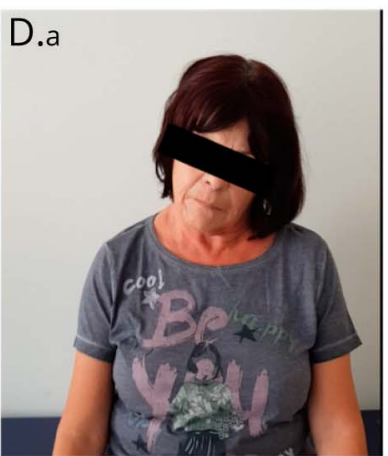

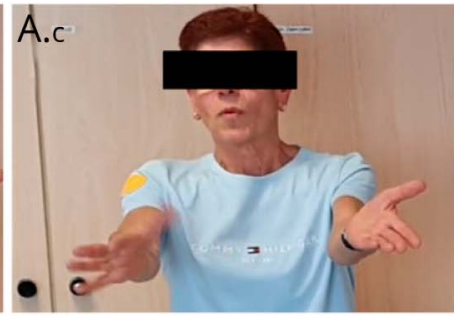
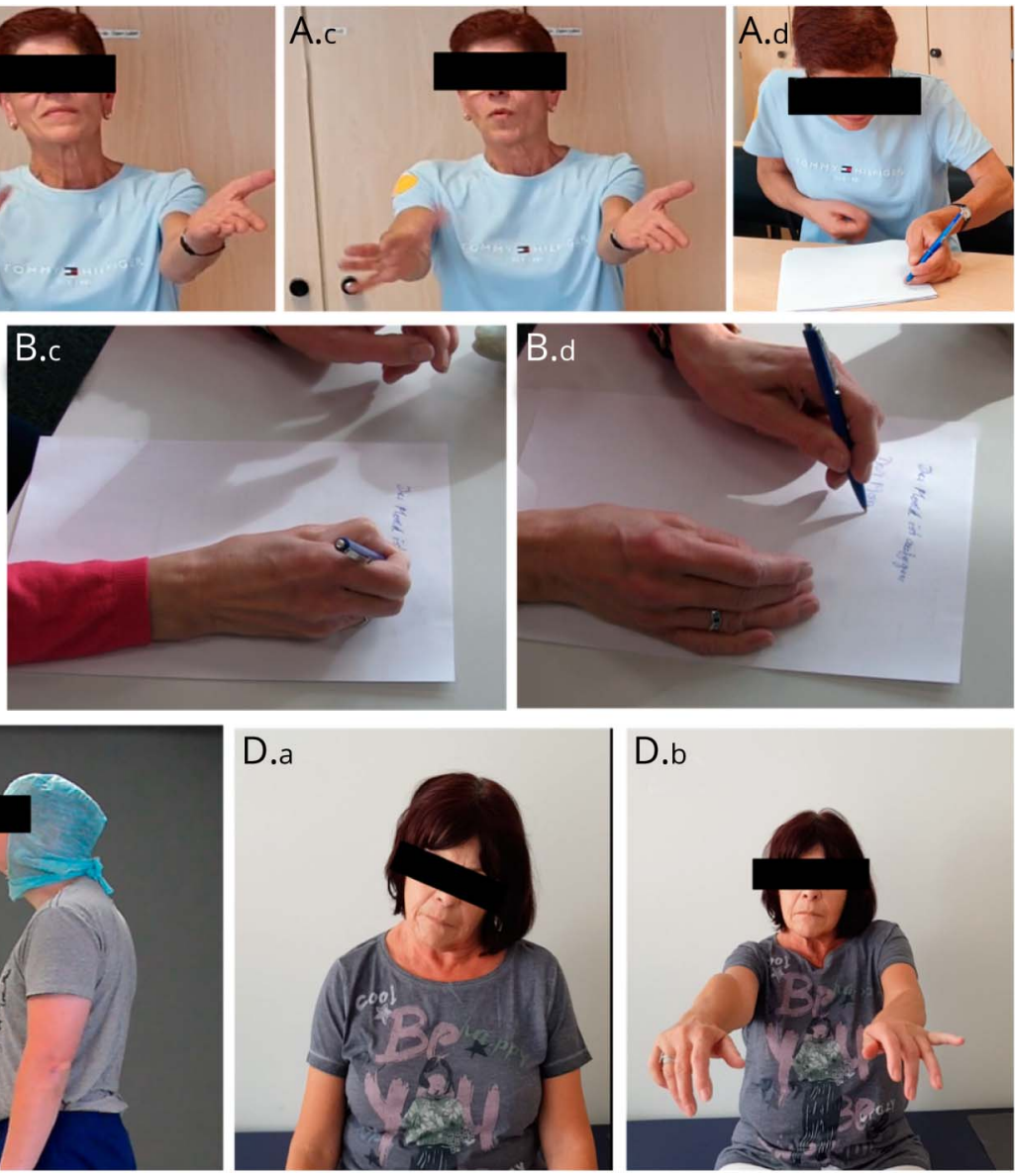

Patient 1 exhibited myoclonic jerks and hyperkinetic movements of the right arm during upper limb posturing (A.a-c) and writer's cramp (A.d). Patient 2 had cervical dystonia (B.a), mild truncal dystonia, and scoliosis (B.b). She also showed hand dystonia and writer's cramp that were more prominent on the right hand (B.C) than on the left (B.d). Patient 3 had cervical dystonia with prominent retro- and torticollis (C.a-b). Patient 4 had cervical dystonia and dystonic postural tremor of the upper limb (D.a-b). All images are snapshots from the supplementary videos (Videos 1-4).

history and brain MRI were unremarkable. At age 52 years, her dystonic symptoms improved under treatments with dopaminergic agents such as levodopa, pramipexole, and ropinirole. Because of diarrhea, weight loss, orthostatic hypertension under levodopa, and undesirable spontaneous orgasms under dopamine agonists, the treatments had to be stopped. The unusual side effect of dopamine agonists in our patient had been reported in a case description. ${ }^{17}$ Currently, cervical dystonia is responsive to botulinum toxin.

\section{Patient 3 [c.1903C>T (p.Arg635Ter)]}

Patient 3, a 43-year-old patient, presented with segmental dystonia beginning with a mild writer's cramp of the right hand at age 33 years. At age 40 years, he first recognized a torticollis to the left. The severity of cervical dystonia progressed over the years, whereas the writer's cramp remained mild (Video 3). Further medical and family history was unremarkable. The patient has 2 healthy children. On physical examination, we observed a retrocaput and torticollis to the left of variable severity. There was no limitation in rotational head movements. Also, anteversion and retroversion were not limited. Writing with the right hand induced a mild cramp and a mild tremor of the right hand. The patient was able to suppress cervical dystonia by a geste antagoniste [Burke-Fahn-Marsden Dystonia Rating Scale (BFMDRS): 10, Toronto Western Spasmodic Torticollis Rating Scale (TWSTRS): 16]. Laboratory examination was not suspicious of any secondary cause of dystonia. MRI of the brain and the cervical spine were normal. Neuropsychiatric examination showed mild mnestic [Parkinson neuropsychometric dementia assessment (PANDA): 23/30 points] but no cognitive impairment. Because of the patient's limited response to trihexyphenidyl and botulinum toxin, he underwent pallidal deep brain stimulation after exclusion of any contraindications and evaluation of the case in an interdisciplinary expert board. Dystonic symptoms improved tremendously under deep brain stimulation [postoperative (12-month follow-up) BFMDRS: 1.5, TWSTRS: $7]$, and the patient does not take any additional medication.

\section{Patient 4 [c.1939C >T (p.Arg647Ter)]}

Patient 4, a 60-year-old woman, noticed involuntary muscle contractions of the right hand at primary school between age 7 and 9 years. From age 40 years on, she demonstrated 
Table 2 Allele Count of pLoFs and Missense Variants in VPS16 in Our In-House Database and in gnomAD Browser Localized in the Transcript NM_022575.3/ENST00000380445.3

\begin{tabular}{llllll}
\hline & Dystonia cohort & $\begin{array}{l}\text { Nondystonia } \\
\text { individuals in-house } \\
(\mathbf{n}=\mathbf{1 1 , 2 5 9 )}\end{array}$ & $\begin{array}{l}\boldsymbol{p} \text { Value } \text { (dystonia } \\
\text { cohort vs nondystonia } \\
\text { individuals in-house) }\end{array}$ & $\begin{array}{l}\text { Allele count in } \\
\text { gnomAD v2.1.1 } \\
\text { (non-neuro, } \\
\mathbf{n = 1 1 4 , 7 0 4})^{\mathbf{2}}\end{array}$ & $\begin{array}{l}\boldsymbol{p} \text { Value (dystonia } \\
\text { cohort vs } \\
\text { gnomAD v2.1.1) }\end{array}$ \\
\hline pLoFs & 4 & 1 & $1.67 \times 10^{-6}$ a & 50 & $9.89 \times 10^{-6}(\mathrm{~ns})$ \\
\hline $\begin{array}{l}\text { Missense variants } \\
\text { (MAF }<\mathbf{0 . 1 \% )}\end{array}$ & 11 & 285 & $0.178(\mathrm{~ns})$ & 8,228 & $0.045(\mathrm{~ns})$ \\
\hline
\end{tabular}

Abbreviations: MAF = minor allele frequency; ns = not significant; pLoFs = predicted loss-of-function variants.

${ }^{a} p<2.5 \times 10^{-6}$ (exome-wide significance determined by the 1-sided Fisher exact test).

progressive dystonia with oromandibular and cervical involvement. Neurologic examination at age 60 years revealed generalized dystonia with prominent cervical involvement. We observed a laterocollis to the left, torticollis to the right, and antecollis with dystonic head tremor (Tsui score 7). In addition, she showed dysphagia, dysarthria, and dystonic postural tremor of the upper extremities, but no resting tremor (Video 4). She had gait difficulties due to intermittent dystonic outward rotation of the right foot. MRI of the brain and electroneuronography investigations were unremarkable. Brain perfusion imaging with SPECT using the trace ECD (ethyl cysteinate dimer) showed a mild hypointensity of the left caudate nucleus. Treatments with levodopa and trihexyphenidyl were ineffective. Currently, the torticollis is responsive to botulinum toxin. She had normal psychomotor development and normal cognition. The family history was unremarkable for neurologic disorders.

\section{Discussion}

We screened our in-house exome and genome data sets and observed a significant enrichment of heterozygous VPS16 pLoFs affecting the canonical transcript (ENST00000380445.3) among patients with dystonia (Table 2). We detected an additional 8 pLoFs affecting only the first exon of a smaller transcript ENST00000380443.3 (comprising 12 exons). The genomic positions of these variants did not overlap with the canonical transcript (Figure $1 \mathrm{~B}$ and $\mathrm{C}$ ) and were only observed in controls. Without the transcript-specific burden analysis considering the likely biological relevance of different transcripts predicted by expression levels, these changes would have distorted the analysis preventing the confirmation of exome-wide significant genotypephenotype associations. Rare missense variants were not significantly enriched in the investigated dystonia cohort.

VPS16 is ubiquitously expressed in all tissues with particularly high expression levels in various brain areas and the nervous system and plays an important role in the endosomal network. ${ }^{18,19}$ The transcript ENST00000380445.3 (NM 022575.3 ) comprises 24 exons and is currently designated as the Ensembl canonical transcript encoding the longest VPS16 coding sequence (Figure 1B). ${ }^{11,20}$ Apart from some exceptions, the longest CCDS has been systematically determined as the canonical transcript for the protein-coding genes and is preferably used for variant annotation and interpretations allowing uniform description of variants and domains. ${ }^{20}$ However, they are not always the most prevalent and/or biologically relevant transcript of a gene. This would require elaborate investigation of regulation, expression, and cellular functions of proteins across different species and cell types. ${ }^{21}$ Recently, a new transcript-level annotation tool based on RNA sequencing data extracted from GTEx $\mathrm{v}^{22}$ has been integrated in gnomAD browser visualizing normalized value of RNA exon expression levels across different cell types as pext (proportion expressed across transcripts) values. ${ }^{4}$ Using this tool, it could be demonstrated that pLoFs of haploinsufficiency disease genes are enriched in highly expressed exons in affected patients, whereas pLoFs in weakly expressed exons had similar enrichment as those of synonymous variants. According to the pext values of VPS16, the first exon of the smaller transcript ENST00000380443.3 has a markedly lower expression in all cell types (Figure 1C). pLoFs affecting this weakly expressed exon were not found in any of the patients with dystonia ( $0 / 280$ cases vs $8 / 11,259$ controls), indicating that these variants are most likely not functionally relevant.

Our investigation detected 3 different VPS16 pLoFs in 4 unrelated individuals of German descent with dystonia and clinical features overlapping those of previously reported VPS16 patients (Table 3). ${ }^{12,13}$ A homozygous missense variant c.156C >A (p.Asn52Lys) in VPS16 was first reported in a consanguineous family with adolescent-onset dystonia consisting of 5 affected family members. CRISPR/Cas9-induced Vps16 c.156C >A mutant mice demonstrated impaired motor function with abnormal behavior comparable to the phenotype of their patients. ${ }^{11}$ Using weighted burden analysis, 5 heterozygous pLoFs and a microdeletion spanning VPS16 have been discovered in a selected cohort of 138 patients with early-onset dystonia. These findings proposed an autosomal dominant inheritance of VPS16-associated generalized dystonia. ${ }^{12}$ In the same study, additional 13 patients were recruited through international collaborations. ${ }^{12}$ Segregation analyses of 9 families confirmed dominant inheritance in 4 of them and a de novo occurrence in a single family. ${ }^{12}$ In the remaining 4 families, the variants were inherited from reportedly healthy parents indicating an incomplete penetrance 


\begin{tabular}{|c|c|c|c|c|c|c|c|c|c|c|}
\hline & This publication & This publication & $\begin{array}{l}\text { This } \\
\text { publication }\end{array}$ & $\begin{array}{l}\text { This } \\
\text { publication }\end{array}$ & Cai et al. 2016 & Steel et al. 2020 & Pott et al. 2020 & $\begin{array}{l}\text { Ostrozovicova } \\
\text { et al. } 2021\end{array}$ & $\begin{array}{l}\text { Li et al. 2021, Mov } \\
\text { Disord }\end{array}$ & $\begin{array}{l}\text { Li et al. 2021, } \\
\text { Parkinsonism } \\
\text { Relat Disord }\end{array}$ \\
\hline Patient & Patient 1 & Patient 2 & Patient 3 & Patient 4 & 5 patients & 19 patients & 1 patient & $\begin{array}{l}2 \text { additional } \\
\text { patients }\end{array}$ & 1 patient & 1 patient \\
\hline Variant & $\begin{array}{l}\text { c.721_727del } \\
\text { p.(Gly241SerfsTer47) } \\
\text { (het) }\end{array}$ & $\begin{array}{l}\text { c. } 1903 C>T \\
\text { p.(Arg635Ter) (het) }\end{array}$ & $\begin{array}{l}\text { c. } 1903 C>T \\
\text { p.(Arg635Ter) } \\
\text { (het) }\end{array}$ & $\begin{array}{l}\text { c.1939C>T } \\
\text { p.(Arg647Ter) } \\
\text { (het) }\end{array}$ & $\begin{array}{l}\text { c.156C>A } \\
\text { p.(Asn52Lys) } \\
\text { (hom) }\end{array}$ & $\begin{array}{l}\text { Different pLoFs } \\
\text { (het) }\end{array}$ & $\begin{array}{l}\text { c.244_ } \\
\text { 259delinsGAGAGC } \\
\text { p.(Lys82GlufsTer124) }\end{array}$ & $\begin{array}{l}\text { c.559C }>\mathrm{T}, \\
\text { p.(Arg187Ter) }\end{array}$ & $\begin{array}{l}\text { c.133_134dup, } \\
\text { p.(Pro46AlafsTer6) }\end{array}$ & $\begin{array}{l}\text { c.1929_1930del, } \\
\text { p.(Lys554Ter) }\end{array}$ \\
\hline Inheritance & $A D$ & $A D$ & $A D$ & $A D$ & AR & $A D$ & $A D$ & $A D$ & AD (paternal) & $A D$ \\
\hline $\begin{array}{l}\text { Age at } \\
\text { onset } \\
\text { (current } \\
\text { age) }\end{array}$ & 26 y (64 y) & 14 y (65 y) & 34 y (46 y) & $\begin{array}{l}\text { Between } 7 \text { and } 9 \\
\text { y (60 y) }\end{array}$ & $\begin{array}{l}\text { Between } 11 \\
\text { and } 14 y_{1} \\
\text { median } 13 \mathrm{y}\end{array}$ & $\begin{array}{l}\text { Between } 3 \text { and } 50 \\
y, \text { median } 12 y\end{array}$ & 16 y (42 y) & 14,25 y $(20,60 y)$ & $9 \mathrm{y}(30 \mathrm{y})$ & 8 y $(29 y)$ \\
\hline $\begin{array}{l}\text { First } \\
\text { symptoms }\end{array}$ & Writer's cramp & Writer's cramp & Writer's cramp & Writer's cramp & $\begin{array}{l}\text { Cervical } \\
\text { dystonia }\end{array}$ & $\begin{array}{l}\text { Writer's cramp (3 } \\
\text { patients), cervical } \\
\text { dystonia, and/or } \\
\text { speech } \\
\text { involvement (8), } \\
\text { oromandibular } \\
\text { dystonia (3), and } \\
\text { upper or lower } \\
\text { limb dystonia (5) }\end{array}$ & Writer's cramp & $\begin{array}{l}\text { Cervical dystonia } \\
\text { with speech } \\
\text { involvement }\end{array}$ & Writer's cramp & Cervical dystonia \\
\hline $\begin{array}{l}\text { Main } \\
\text { diagnosis }\end{array}$ & Myoclonus dystonia & Segmental dystonia & $\begin{array}{l}\text { Segmental } \\
\text { dystonia }\end{array}$ & $\begin{array}{l}\text { Generalized } \\
\text { dystonia with } \\
\text { predominant } \\
\text { cervical } \\
\text { involvement }\end{array}$ & $\begin{array}{l}\text { Generalized } \\
\text { dystonia (4 } \\
\text { patients) and } \\
\text { cervical } \\
\text { dystonia (1) }\end{array}$ & $\begin{array}{l}\text { Early-onset } \\
\text { progressive } \\
\text { dystonia (focal, } \\
\text { segmental, and } \\
\text { generalized) }\end{array}$ & $\begin{array}{l}\text { Generalized dystonia } \\
\text { with myoclonus }\end{array}$ & $\begin{array}{l}\text { Progressive } \\
\text { generalized } \\
\text { dystonia }\end{array}$ & $\begin{array}{l}\text { Generalized } \\
\text { dystonia }\end{array}$ & $\begin{array}{l}\text { Generalized } \\
\text { dystonia }\end{array}$ \\
\hline $\begin{array}{l}\text { Affected } \\
\text { body parts }\end{array}$ & Hand and neck & $\begin{array}{l}\text { Hand (right > left), } \\
\text { neck, left foot, trunk, } \\
\text { and speech }\end{array}$ & Hand and neck & $\begin{array}{l}\text { Hand, neck, } \\
\text { oromandibular, } \\
\text { and upper and } \\
\text { lower limbs }\end{array}$ & $\begin{array}{l}\text { Head, neck, } \\
\text { trunk, and } \\
\text { upper and } \\
\text { lower limbs }\end{array}$ & $\begin{array}{l}\text { Hand, neck, } \\
\text { oromandibular, } \\
\text { and upper and } \\
\text { lower limbs }\end{array}$ & $\begin{array}{l}\text { Hand, neck, } \\
\text { oromandibular, and } \\
\text { trunk }\end{array}$ & $\begin{array}{l}\text { Neck, cranial } \\
\text { laryngeal, trunk, } \\
\text { limbs (1) } \\
\text { oromandibular, } \\
\text { and speech }\end{array}$ & $\begin{array}{l}\text { Bulbar, } \\
\text { oromandibular, } \\
\text { neck, trunk, and } \\
\text { upper limb }\end{array}$ & $\begin{array}{l}\text { Neck, } \\
\text { oromandibular, } \\
\text { dysphonia, } \\
\text { dysphagia, and } \\
\text { limbs }\end{array}$ \\
\hline Ambulant & Yes & Yes & Yes & Yes & No (4), yes (1) & No (3), yes (16) & Yes & $\mathrm{n} / \mathrm{a}$ & $\mathrm{n} / \mathrm{a}$ & Yes \\
\hline Tremor & + & + & + & + & $\mathrm{n} / \mathrm{a}$ & $\mathrm{n} / \mathrm{a}$ & - & $\mathrm{n} / \mathrm{a}$ & $\mathrm{n} / \mathrm{a}$ & $\mathrm{n} / \mathrm{a}$ \\
\hline $\begin{array}{l}\text { Other } \\
\text { neurologic }\end{array}$ & $\begin{array}{l}\text { Hyperkinetic } \\
\text { movements and } \\
\text { head tremor }\end{array}$ & None & None & Head tremor & $\mathrm{n} / \mathrm{a}$ & $\begin{array}{l}\text { Spasticity (1 } \\
\text { patient), epilepsy } \\
\text { (2), non-REM }\end{array}$ & $\mathrm{n} / \mathrm{a}$ & $\begin{array}{l}\text { Neuropsychiatric } \\
\text { symptoms } \\
\text { (anxiety, }\end{array}$ & $\mathrm{n} / \mathrm{a}$ & $\mathrm{n} / \mathrm{a}$ \\
\hline
\end{tabular}


Table 3 Clinical Features of VPS16 Patients With Dystonia (continued)

\begin{tabular}{|c|c|c|c|c|c|c|c|c|c|c|}
\hline & This publication & This publication & $\begin{array}{l}\text { This } \\
\text { publication }\end{array}$ & $\begin{array}{l}\text { This } \\
\text { publication }\end{array}$ & Cai et al. 2016 & Steel et al. 2020 & Pott et al. 2020 & $\begin{array}{l}\text { Ostrozovicova } \\
\text { et al. } 2021\end{array}$ & $\begin{array}{l}\text { Li et al. 2021, Mov } \\
\text { Disord }\end{array}$ & $\begin{array}{l}\text { Li et al. 2021, } \\
\text { Parkinsonism } \\
\text { Relat Disord }\end{array}$ \\
\hline $\begin{array}{l}\text { or clinical } \\
\text { features }\end{array}$ & & & & & & $\begin{array}{l}\text { parasomnia (1), } \\
\text { and psychiatric } \\
\text { symptoms (7) }\end{array}$ & & $\begin{array}{l}\text { depression, and } \\
\text { emotional } \\
\text { lability) }\end{array}$ & & \\
\hline $\begin{array}{l}\text { Current } \\
\text { treatment }\end{array}$ & $\begin{array}{l}\text { Botulinum toxin } \\
\text { (responsive for the } \\
\text { torticollis) and } \\
\text { gabapentin (mild } \\
\text { improvement of } \\
\text { myoclonus) }\end{array}$ & $\begin{array}{l}\text { Pramipexole (initiated } \\
\text { in low dosage due to } \\
\text { previous side effects, } \\
\text { was partially } \\
\text { responsive in the past) }\end{array}$ & $\begin{array}{l}\text { Responded to } \\
\text { deep brain } \\
\text { stimulation }\end{array}$ & $\begin{array}{l}\text { Botulinum toxin } \\
\text { (responsive for } \\
\text { the torticollis) }\end{array}$ & $\mathrm{n} / \mathrm{a} /$ & $\begin{array}{l}\text { Partial response to } \\
\text { L-dopa ( } 3 \text { patients), } \\
\text { trihexyphenidyl } \\
\text { (1), botulinum } \\
\text { toxin (3), or deep } \\
\text { brain stimulation } \\
\text { (3) }\end{array}$ & $\begin{array}{l}\text { Responded to deep } \\
\text { brain stimulation } \\
\text { (significant } \\
\text { improvement) }\end{array}$ & $\begin{array}{l}\text { Botulinum toxin } \\
\text { (partial } \\
\text { improvement) } \\
\text { and deep brain } \\
\text { stimulation } \\
\text { (significant } \\
\text { improvement) }\end{array}$ & $\mathrm{n} / \mathrm{a}$ & $\begin{array}{l}\text { Selective peripheral } \\
\text { denervation surgery } \\
\text { (improvement of } \\
\text { cervical dystonia) }\end{array}$ \\
\hline $\begin{array}{l}\text { Past } \\
\text { treatments }\end{array}$ & $\begin{array}{l}\text { Tetrabenazine, } \\
\text { tiapride, levodopa, } \\
\text { baclofen, olanzapine, } \\
\text { primidone, and } \\
\text { topiramate }\end{array}$ & $\begin{array}{l}\text { Levodopa (responsive } \\
\text { in the past, side } \\
\text { effects), pramipexole } \\
\text { and ropinirole } \\
\text { (responsive in the past, } \\
\text { side effects), and } \\
\text { botulinum toxin } \\
\text { (responsive for the } \\
\text { cervical dystonia) }\end{array}$ & $\begin{array}{l}\text { Trihexyphenidyl } \\
\text { and botulinum } \\
\text { toxin }\end{array}$ & $\begin{array}{l}\text { Levodopa and } \\
\text { trihexyphenidyl }\end{array}$ & $\mathrm{n} / \mathrm{a}$ & $\mathrm{n} / \mathrm{a}$ & Levodopa & Levodopa & $\begin{array}{l}\text { Trihexyphenidyl, } \\
\text { levodopa, } \\
\text { baclofen, and } \\
\text { clonazepam }\end{array}$ & $\begin{array}{l}\text { Botulinum toxin } \\
\text { (initially responsive } \\
\text { for the torticollis, } \\
\text { effect declined with } \\
\text { repeated injections), } \\
\text { trihexyphenidyl, } \\
\text { levodopa, } \\
\text { carbamazepine, and } \\
\text { clonazepam }\end{array}$ \\
\hline MRI & Unremarkable & Unremarkable & Unremarkable & Unremarkable & $\begin{array}{l}\text { Unremarkable } \\
\text { (1 patient) }\end{array}$ & $\begin{array}{l}\text { Unremarkable ( } 7 \\
\text { patients), bilateral } \\
\text { hypointensity of } \\
\text { the globi pallidi (4), } \\
\text { and mild cerebral } \\
\text { atrophy (4) }\end{array}$ & Unremarkable & Unremarkable & Unremarkable & $\mathrm{n} / \mathrm{a}$ \\
\hline
\end{tabular}

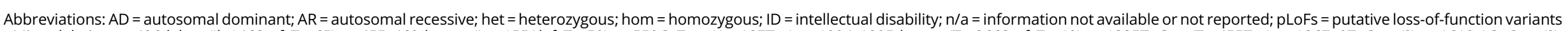

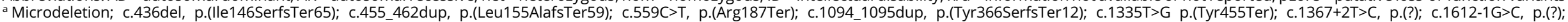
c.1720+1G>C, p.(?); c.1903C>T p.(Arg635Ter); c.1988_1989insG, p.(Asn663LysfsTer). 
of VPS16 pLoFs. ${ }^{12}$ Subsequently, 114 German patients with early-onset dystonia were screened for variants in VPS16 by Sanger sequencing and another frameshift variant was identified in 1 individual in a different study. ${ }^{13}$ During the revision process of this article, additional VPS16 cases were published and subsequently included in the phenotypic review of the associated clinical phenotypes (Table 3 ). ${ }^{23-25}$

Overall, all 28 affected individuals with heterozygous pLoFs in VPS16 presented with a progressive dystonia often manifesting as writer's cramp and cervical, oromandibular, or limb dystonia between age 3 and 50 years (mean 15 years). Disease severity varied among affected carriers; although some maintained focal dystonia, others developed segmental or generalized dystonia with hand, neck, oromandibular, limb, and/or trunk involvement (Table 3). Patient 1 additionally exhibited progressive myoclonic jerks and hyperkinetic movements (Video 1). In all 4 patients reported in this study, writer's cramp was the first sign of dystonia between age 7 and 34 years (mean 20 years). They had a documented disease course of 12-53 years (mean 39 years), with the 2 oldest patients being 65 years old at the time of publication. Three patients (patients 1, 2, and 4) partially responded to botulinum toxin, and patient 3 had tremendous improvement of dystonia under deep brain stimulation. Dopaminergic agents such as levodopa, pramipexole, and ropinirole were effective in patient 2, but they had to be reduced and/or stopped due to side effects (Table 3). Some of the previously reported VPS16 patients also had partial response to levodopa and/or trihexyphenidyl that can be considered as well. ${ }^{12}$ All 4 patients reported in this study remained ambulant, and brain MRI scans were unremarkable. Although most previously reported individuals remained ambulant as well, 3 individuals lost their ability to walk in adulthood. ${ }^{12}$ Some also had mild to moderate intellectual disability $(7 / 28)$, seizures $(2 / 28)$, and psychiatric symptoms $(9 / 28),{ }^{12,13}$ which were not observed in our patients. Other movement abnormalities such as spasticity were described only in single patients (Table 3$){ }^{12}$ The recessive family with the homozygous missense variant c.156C $>$ A (p.Asn52Lys) demonstrated a comparable phenotype. In these individuals, first symptoms were cervical dystonia, and in 4 of 5 , the disease progressed to generalized dystonia involving the trunk, face, tongue, jaw, and parts of the extremities resulting in severe motor disability. ${ }^{11}$ Intellectual disability or other neurologic features were not described in the recessive family.

In conclusion, our results provide additional evidence of heterozygous pLoFs in VPS16 to be implicated in autosomal dominant dystonia. pLoFs affecting the weakly expressed exon from a noncanonical transcript were not found in patients with dystonia, and knowledge on exon resolution expression levels proved to be crucial for variant interpretation. been associated with dystonia phenotypes so far and were not enriched in the investigated dystonia cohort, extended research studies involving segregation analysis and functional Although heterozygous VPS16 missense variants have not

readouts may be useful to determine the pathogenicity of rare missense changes. The disease severity, age at onset, and response to treatment were variable among the affected individuals. Additional clinical features such as hyperkinetic movements, myoclonus, spasticity, epilepsy, mild intellectual disability, and psychiatric symptoms have also been reported in single cases. Furthermore, pLoFs have also been observed in reportedly healthy family members, indicating that these variants may exhibit incomplete penetrance and other so far unknown factors may contribute to disease manifestation.

\section{Acknowledgment}

The authors thank the patients for their cooperation and consent to the publication.

\section{Study Funding}

TBH was supported by the Deutsche Forschungsgemeinschaft (DFG, German Research Foundation) under the project number 418081722. J.N.P-S. was supported by the Cologne Clinician Scientist Program (CCSP)/Faculty of Medicine/ University of Cologne, funded by the German Research Foundation (DFG, FI 773/15-1).

\section{Disclosure}

The authors have no disclosures to report. Go to Neurology. org/NG for full disclosures.

\section{Publication History}

Received by Neurology: Genetics May 7, 2021. Accepted in final form October 8, 2021.

Appendix Authors

\begin{tabular}{|c|c|c|}
\hline Name & Location & Contribution \\
\hline Joohyun Park, MD & $\begin{array}{l}\text { Institute of Medical } \\
\text { Genetics and Applied } \\
\text { Genomics, University of } \\
\text { Tübingen, Tübingen, } \\
\text { Germany }\end{array}$ & $\begin{array}{l}\text { Conceptualized and } \\
\text { designed the study, } \\
\text { collected and analyzed } \\
\text { the data, and drafted the } \\
\text { manuscript. }\end{array}$ \\
\hline $\begin{array}{l}\text { Annemarie } \\
\text { Reilaender, MD }\end{array}$ & $\begin{array}{l}\text { Department of } \\
\text { Neurology University } \\
\text { Hospital, Goethe } \\
\text { University Frankfurt, } \\
\text { Frankfurt, Germany }\end{array}$ & $\begin{array}{l}\text { Contributed to } \\
\text { phenotyping, acquisition } \\
\text { of patient data, and } \\
\text { revised the manuscript } \\
\text { for intellectual content. }\end{array}$ \\
\hline $\begin{array}{l}\text { Jan N. Petry- } \\
\text { Schmelzer, MD }\end{array}$ & $\begin{array}{l}\text { University of Cologne, } \\
\text { Faculty of Medicine and } \\
\text { University Hospital } \\
\text { Cologne, Department of } \\
\text { Neurology, Cologne, } \\
\text { Germany }\end{array}$ & $\begin{array}{l}\text { Contributed to } \\
\text { phenotyping, acquisition } \\
\text { of patient data, and } \\
\text { revised the manuscript } \\
\text { for intellectual content. }\end{array}$ \\
\hline Petra Stöbe, PhD & $\begin{array}{l}\text { Institute of Medical } \\
\text { Genetics and Applied } \\
\text { Genomics, University of } \\
\text { Tübingen, Tübingen, } \\
\text { Germany }\end{array}$ & $\begin{array}{l}\text { Contributed to analysis } \\
\text { and interpretation of } \\
\text { genetic data and and } \\
\text { revised the manuscript } \\
\text { for intellectual content. }\end{array}$ \\
\hline Isabell Cordts, MD & $\begin{array}{l}\text { Department of } \\
\text { Neurology, Klinikum } \\
\text { rechts der Isar, Technical } \\
\text { University Munich, } \\
\text { Munich, Germany }\end{array}$ & $\begin{array}{l}\text { Contributed to } \\
\text { phenotyping, analysis of } \\
\text { data, and revised the } \\
\text { manuscript for } \\
\text { intellectual content. }\end{array}$ \\
\hline
\end{tabular}


Appendix (continued)

\begin{tabular}{|c|c|c|}
\hline Name & Location & Contribution \\
\hline $\begin{array}{l}\text { Florian Harmuth, } \\
\text { MS }\end{array}$ & $\begin{array}{l}\text { Institute of Medical } \\
\text { Genetics and Applied } \\
\text { Genomics, University of } \\
\text { Tübingen, Tübingen, } \\
\text { Germany }\end{array}$ & $\begin{array}{l}\text { Contributed to analysis } \\
\text { and interpretation of } \\
\text { genetic data and } \\
\text { revised the } \\
\text { manuscript for } \\
\text { intellectual content. }\end{array}$ \\
\hline $\begin{array}{l}\text { Maren } \\
\text { Rautenberg, PhD }\end{array}$ & $\begin{array}{l}\text { Institute of Medical } \\
\text { Genetics and Applied } \\
\text { Genomics, University of } \\
\text { Tübingen, Tübingen, } \\
\text { Germany }\end{array}$ & $\begin{array}{l}\text { Contributed to analysis } \\
\text { and interpretation of } \\
\text { genetic data and revised } \\
\text { the manuscript for } \\
\text { intellectual content. }\end{array}$ \\
\hline Sarah E. Woerz, MD & $\begin{array}{l}\text { Institute of Medical } \\
\text { Genetics and Applied } \\
\text { Genomics, University of } \\
\text { Tübingen, Tübingen, } \\
\text { Germany }\end{array}$ & $\begin{array}{l}\text { Contributed to analysis } \\
\text { and interpretation of } \\
\text { genetic data and revised } \\
\text { the manuscript for } \\
\text { intellectual content. }\end{array}$ \\
\hline $\begin{array}{l}\text { German Demidov, } \\
\text { PhD }\end{array}$ & $\begin{array}{l}\text { Institute of Medical } \\
\text { Genetics and Applied } \\
\text { Genomics, University of } \\
\text { Tübingen, Tübingen, } \\
\text { Germany }\end{array}$ & $\begin{array}{l}\text { Contributed to genetic } \\
\text { and statistical analysis } \\
\text { and revised the } \\
\text { manuscript for } \\
\text { intellectual } \\
\text { content. }\end{array}$ \\
\hline Marc Sturm, PhD & $\begin{array}{l}\text { Institute of Medical } \\
\text { Genetics and Applied } \\
\text { Genomics, University of } \\
\text { Tübingen, Tübingen, } \\
\text { Germany }\end{array}$ & $\begin{array}{l}\text { Contributed to analysis } \\
\text { and interpretation of } \\
\text { genetic data } \\
\text { and revised the } \\
\text { manuscript for } \\
\text { intellectual content. }\end{array}$ \\
\hline $\begin{array}{l}\text { Stephan Ossowski, } \\
\text { PhD }\end{array}$ & $\begin{array}{l}\text { Institute of Medical } \\
\text { Genetics and Applied } \\
\text { Genomics, University of } \\
\text { Tübingen, Tübingen, } \\
\text { Germany }\end{array}$ & $\begin{array}{l}\text { Contributed to analysis } \\
\text { and interpretation of } \\
\text { genetic and } \\
\text { statistical data and } \\
\text { revised the } \\
\text { manuscript for } \\
\text { intellectual content. }\end{array}$ \\
\hline $\begin{array}{l}\text { Eva M.C. } \\
\text { Schwaibold, MD }\end{array}$ & $\begin{array}{l}\text { Institute of Human } \\
\text { Genetics, Heidelberg } \\
\text { University, Heidelberg, } \\
\text { Germany }\end{array}$ & $\begin{array}{l}\text { Contributed to } \\
\text { phenotyping, } \\
\text { acquisition of patient } \\
\text { data, and revised the } \\
\text { manuscript for } \\
\text { intellectual content. }\end{array}$ \\
\hline $\begin{array}{l}\text { Gilbert } \\
\text { Wunderlich, MD }\end{array}$ & $\begin{array}{l}\text { University of Cologne, } \\
\text { Faculty of Medicine and } \\
\text { University Hospital } \\
\text { Cologne, Centre for Rare } \\
\text { Diseases, Cologne, } \\
\text { Germany }\end{array}$ & $\begin{array}{l}\text { Contributed to } \\
\text { phenotyping, acquisition } \\
\text { of patient data, and } \\
\text { revised the manuscript } \\
\text { for intellectual content. }\end{array}$ \\
\hline $\begin{array}{l}\text { Sebastian Paus, } \\
\text { MD }\end{array}$ & $\begin{array}{l}\text { Department of } \\
\text { Neurology, GFO Clinics } \\
\text { Troisdorf, Troisdorf, } \\
\text { Germany }\end{array}$ & $\begin{array}{l}\text { Contributed to } \\
\text { phenotyping, } \\
\text { acquisition of patient } \\
\text { data, and revised the } \\
\text { manuscript for } \\
\text { intellectual content. }\end{array}$ \\
\hline Carsten Saft, MD & $\begin{array}{l}\text { Department of } \\
\text { Neurology, Huntington } \\
\text { Centre NRW, Ruhr- } \\
\text { University Bochum, St. } \\
\text { Josef-Hospital, Bochum, } \\
\text { Germany }\end{array}$ & $\begin{array}{l}\text { Contributed to } \\
\text { phenotyping, } \\
\text { acquisition of patient } \\
\text { data, and revised the } \\
\text { manuscript for } \\
\text { intellectual } \\
\text { content. }\end{array}$ \\
\hline
\end{tabular}

Appendix (continued)

\begin{tabular}{lll}
\hline Name & Location & Contribution \\
\hline $\begin{array}{l}\text { Tobias B. Haack, } \\
\text { MD }\end{array}$ & $\begin{array}{l}\text { Centre for Rare Diseases, } \\
\text { University of Tübingen, } \\
\text { Tübingen, Germany }\end{array}$ & $\begin{array}{l}\text { Conceptualized and } \\
\text { supervised the study, } \\
\text { drafted the manuscript, } \\
\text { and revised the } \\
\text { manuscript for } \\
\text { intellectual content. }\end{array}$ \\
\end{tabular}

\section{References}

1. de Carvalho Aguiar PM, Ozelius LJ. Classification and genetics of dystonia. Lancet Neurol. 2002;1(5):316-325.

2. Zech M, Jech R, Boesch S, et al. Monogenic variants in dystonia: an exome-wide sequencing study. Lancet Neurol. 2020;19(11):908-918.

3. Powis Z, Towne MC, Hagman KDF, et al. Clinical diagnostic exome sequencing in dystonia: genetic testing challenges for complex conditions. Clin Genet. 2020;97(2):305-311.

4. Cummings BB, Karczewski KJ, Kosmicki JA, et al. Transcript expression-aware annotation improves rare variant interpretation. Nature. 2020;581(7809):452-458.

5. Wang ET, Sandberg R, Luo S, et al. Alternative isoform regulation in human tissue transcriptomes. Nature. 2008;456(7221):470-476.

6. Richards S, Aziz N, Bale S, et al. Standards and guidelines for the interpretation of sequence variants: a joint consensus recommendation of the American college of medical genetics and genomics and the association for molecular pathology. Genet Med. 2015;17(5):405-424.

7. Balderhaar HJ, Ungermann C. CORVET and HOPS tethering complexes - coordinators of endosome and lysosome fusion. J Cel Sci. 2013;126(Pt 6):1307-1316.

8. Zhang J, Lachance V, Schaffner A, et al. A founder mutation in VPS11 causes an autosomal recessive leukoencephalopathy linked to autophagic defects. Plos Genet. 2016;12(4):e1005848.

9. Edvardson S, Gerhard F, Jalas C, et al. Hypomyelination and developmental delay associated with VPS11 mutation in Ashkenazi-Jewish patients. J Med Genet. 2015, 52(11):749-753

10. Wartosch L, Günesdogan U, Graham SC, Luzio JP. Recruitment of VPS33A to HOPS by VPS16 is required for lysosome fusion with endosomes and autophagosomes. Traffic. 2015;16(7):727-742.

11. Cai X, Chen X, Wu S, et al. Homozygous mutation of VPS16 gene is responsible for an autosomal recessive adolescent-onset primary dystonia. Sci Rep. 2016;6:25834.

12. Steel D, Zech M, Zhao C, et al. Loss-of-Function variants in HOPS complex genes VPS16 and VPS41 cause early onset dystonia associated with lysosomal abnormalities. Ann Neurol. 2020;88(5):867-877.

13. Pott $\mathrm{H}$, Bruggemann N, Reese $\mathrm{R}$, et al. Truncating VPS16 mutations are rare in early onset dystonia. Ann Neurol. 2021;89(3):625-626.

14. Hörtnagel K, Krägeloh-Mann I, Bornemann A, et al. The second report of a new hypomyelinating disease due to a defect in the VPS11 gene discloses a massive lysosomal involvement. J Inherit Metab Dis. 2016;39(6):849-857.

15. van der Welle REN, Jobling R, Burns C, et al. VPS41 recessive mutation causes ataxia and dystonia with retinal dystrophy and mental retardation by inhibiting HOPS function and mTORC1 signaling. bioRxiv. 2019. doi:10.1101/2019.12.18.867333.

16. Fritzen D, Kuechler A, Grimmel M, et al. De novo FBXO11 mutations are associated with intellectual disability and behavioural anomalies. Hum Genet. 2018;137(5):401-411.

17. Kaut O, Asmus F, Paus S. Spontaneous unwelcome orgasms due to pramipexole and ropinirole. Mov Disord. 2012;27(10):1327-1328.

18. Kim BY, Ueda M, Nakamura Y, Kohsaka S, Akazawa C. Expression of the mammalian homologue of vacuolar protein sorting $16(\mathrm{Vps} 16 \mathrm{p})$ in the mouse and rat brain. Neurosci Lett. 2004;355(3):217-220.

19. Huizing M, Didier A, Walenta J, Anikster Y, Gahl WA, Krämer H. Molecular cloning and characterization of human VPS18, VPS 11, VPS16, and VPS33. Gene. 2001, 264(2):241-247.

20. Hubbard TJ, Aken BL, Ayling S, et al. Ensembl 2009. Nucleic Acids Res. 2009;37(Database issue):D690-D697.

21. Aken BL, Ayling S, Barrell D, et al. The Ensembl Gene Annotation System. Database;2016.

22. Consortium GT, Laboratory DA, Coordinating Center -Analysis Working G, et al. Genetic effects on gene expression across human tissues. Nature. 2017;550(7675):204-213.

23. Li LX, Jiang LT, Liu Y, et al. Mutation screening of VPS16 gene in patients with isolated dystonia. Parkinsonism Relat Disord. 2021;83:63-65.

24. Li XY, Wang L, Guo Y, Wan XH. Mutations in the VPS16 gene in 56 early-onset dystonia patients. Mov Disord. 2021;36(3):780-781.

25. Ostrozovicova M, Jech R, Steel D, et al. A recurrent VPS16 p.Arg $187^{*}$ nonsense variant in early-onset generalized dystonia. Mov Disord. 2021;36(8):1984-1985 


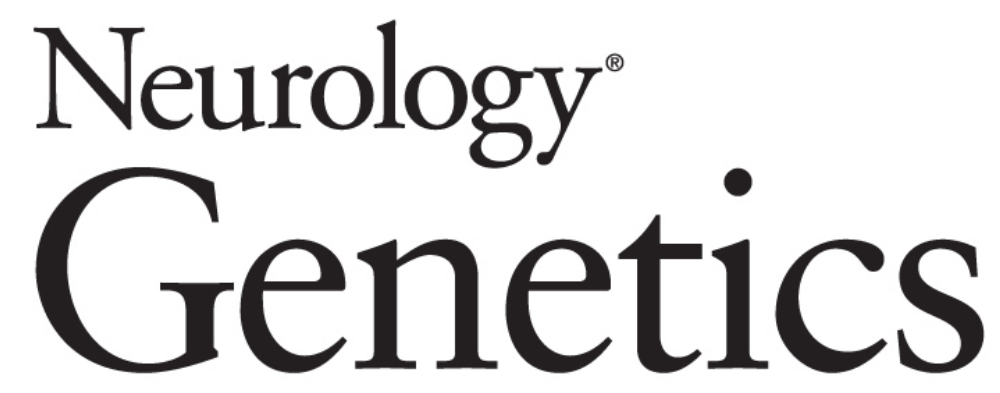

Transcript-Specific Loss-of-Function Variants in VPS16 Are Enriched in Patients With Dystonia

Joohyun Park, Annemarie Reilaender, Jan N. Petry-Schmelzer, et al.

Neurol Genet 2022;8;

DOI 10.1212/NXG.0000000000000644

This information is current as of December 7, 2021

Neurol Genet is an official journal of the American Academy of Neurology. Published since April 2015, it is an open-access, online-only, continuous publication journal. Copyright Copyright ( 2021 The Author(s).

Published by Wolters Kluwer Health, Inc. on behalf of the American Academy of Neurology.. All rights reserved. Online ISSN: 2376-7839.

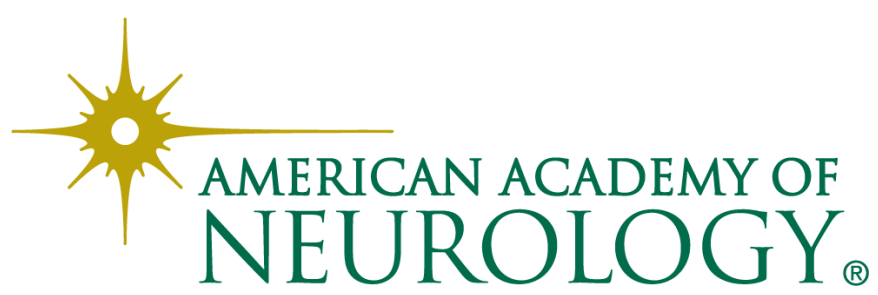




\section{Updated Information \& Services}

References

Subspecialty Collections

Permissions \& Licensing

Reprints including high resolution figures, can be found at:

http://ng.neurology.org/content/8/1/e644.full.html

This article cites 24 articles, 1 of which you can access for free at: http://ng.neurology.org/content/8/1/e644.full.html\#\#ref-list-1

This article, along with others on similar topics, appears in the following collection(s):

Association studies in genetics

http://ng.neurology.org//cgi/collection/association_studies_in_genetics Clinical neurology examination

http://ng.neurology.org//cgi/collection/clinical_neurology_examination

\section{Dystonia}

http://ng.neurology.org//cgi/collection/dystonia

Myoclonus

http://ng.neurology.org//cgi/collection/myoclonus

Information about reproducing this article in parts (figures,tables) or in its entirety can be found online at:

http://ng.neurology.org/misc/about.xhtml\#permissions

Information about ordering reprints can be found online: http://ng.neurology.org/misc/addir.xhtml\#reprintsus

Neurol Genet is an official journal of the American Academy of Neurology. Published since April 2015, it is an open-access, online-only, continuous publication journal. Copyright Copyright ( 2021 The Author(s). Published by Wolters Kluwer Health, Inc. on behalf of the American Academy of Neurology.. All rights reserved. Online ISSN: 2376-7839.

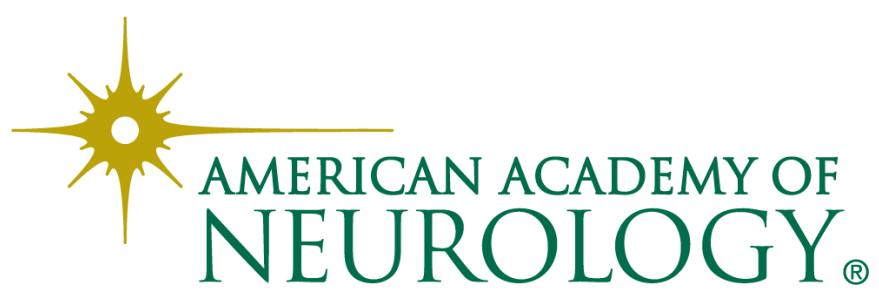

